\title{
The Effect of Leadership and Motivation on Employee Performance at PT. Prima Lestari in Tangerang
}

\author{
Lia Asmalah ${ }^{1}$, Zacharia Rialmi ${ }^{2}$ \\ 1.2 Universitas Pamulang \\ E-mail: dosen01644@unpam.ac.id
}

(Received: December-2018; Reviewed: January-2019; Accepted: February-2019;

Avalaibel Online: February-2019; Published: March-2019)

(7) \& This is an open access article distributed under the Creative Commons Attribution License

EY NC CC-BY-NC-4.0 @2019 by author (https://creativecommons.org/licenses/by-nc/4.0/)

\begin{abstract}
Human resources play an important role in company management. The purpose of this study was to determine the effect of leadership and work motivation on employee performance at PT. Prima Lestari. The method used is descriptive method with an associative approach. The sampling technique used was proportional random sampling using a saturated sampling technique method with a sample of 95 respondents. The analysis tool uses a validity test, reliability test, classic assumption test, regression test, correlation test, coefficient of determination test and hypothesis test. The results of this study are that there is a positive and partially significant effect between leadership on employee performance at PT. Prima Lestari with a contribution of $32.6 \%$, the hypothesis test obtained $t$ count $>t_{\text {table }}$ or $(6,710>1,986)$. Work motivation has a positive and significant effect on employee performance by $42 \%$, the hypothesis test obtained $t_{\text {count }}>t_{\text {table }}$ or $(8.214>1.986)$. There is a positive and significant effect between leadership and work motivation on employee performance with an influence contribution of $48.3 \%$ while the remaining $51.7 \%$ is influenced by other factors. Hypothesis testing test obtained $\mathrm{F}_{\text {coun }} \mathrm{t}>\mathrm{F}_{\text {table }}$ or (43.020) $2,700)$, it is also strengthened by a significance of $0,000<0.05$.
\end{abstract}

Keywords: Leadership; motivation; employee performance

\section{INTRODUCTION}

In running a business in an organization, the role of employees is very important because the human element is one of the elements that can play an active role in the policy and achievement of organizational goals. With reliable human resources, the company's operational activities will run smoothly (Darsono, 2011; Elmi, 2018; Panggabean, 2013; Rivai \& Sagala, 2009). Human resources play an important role in company management. In this case that human resources are the main key that must be able to full attention to all their needs. Human resources are the driving force of the company. The progress of a company is very dependent on the human resources that exist in a company by giving authority and responsibility in managing activities (Sakban, Nurmal, \& Bin Ridwan, 2019; Sari, 2008; Yusuf, 2016). 
Human resources are required to be able to complete their tasks and responsibilities effectively and efficiently. The success of human resources can be measured through customer satisfaction, reduced number of complaints and achievement of work targets (Afshar \& Corresponding, 2011; Opka, 2008; Sugiati, Thoyib, Hadiwidjoyo, \& Setiawan, 2013; Swastha, Basu, 2014). The performance of the employees of PT. Prima Lestari can be measured by completing its tasks effectively and efficiently as well as performing its functions and functions, and it is all directly proportional to the success of a company. In every company, these human roles can cooperate with each other to achieve goals by utilizing existing human resources.

Optimal employee performance, which is good is performance that can be measured by quantitative aspects that describe the work processes of employees who get support from the company, supporting work conditions, able to complete tasks quickly and well, the number of errors can be minimized, the ability of resources that meet expectations and optimal quality of work (Opka, 2008; Swastha, Basu, 2014). Besides that, qualitative aspects also play an important role, especially regarding the quality of work produced, timeliness, ability and work skills as well as the ability to evaluate in organizations.

Based on the pre-research observations conducted by researchers, there are some deficiencies or gaps between ideal conditions and real conditions that exist in the field between employee performance so far as the implementation of the deficiencies between leadership factors and work motivation of existing employees. This is supported by a number of internal assessments conducted by companies where their achievements do not always meet the expectations set (Akib \& Darwis, 2015; Sunarsi, 2014, 2018a, 2018b).

Leadership is one of the biggest factors that can make the performance of the human resources or employees of the company better (Sri Wiranti, 2009; Syarifudin, 2004; Yudiaatmaja, 2013). One of the characteristics of a leader based on the theory of leadership traits is that one of them has a higher intelligence compared to being led (Carefully et al., 2000; Situmorang, 2011; Wahjosumidjo, 2011).

Likewise, the evaluation of motivation is also very important because motivation can encourage a person to be happy to do his job well. Overall achievement value of collective work motivation at PT. Prima Lestari in Tangerang from 2018 showed that achievement was not optimal. Motivation in achieving certain positions and the hope of getting rewards results are poor, while the challenges of work with sufficient value and job responsibilities and the existence of employee welfare expectations are only at moderate assessment levels. The absence of a very good achievement indicates that employee work motivation is in need of serious attention to company management.

Performance appraisal for employees plays an important role in the organization (Rani \& Mayasari, 2016; Siti Noni Evita, Wa Ode Zusnita Muizu, 2017). Information regarding employee performance is obtained through performance appraisals. From the results of employee performance evaluations, it can be seen whether an employee can work well or not as seen from the assessment categories that are compared between benchmarks of organizational performance appraisal with employee performance. The achievement of production in 2014 was 94\%. In 2015 it was 93\%. In 2016 it was $95 \%$, in 2017 it was 94\%, the last in 2018 was $90 \%$. This shows that the work productivity of employees is low because it does not reach the desired target of the company.

\section{METHOD}

The type of data used is quantitative with primary data sources by distributing questionnaires which are then carried out tabulation and feasibility analysis as well as secondary data from the various scientific literature. The population in this study were employees of PT. Prima Lestari-Tangerang. Sampling was used saturation sampling technique that is 95 
employees. The instrument testing uses validity and reliability tests. From the validity and reliability test stated valid and reliable, this is evidenced by the value of $r$ count $>r$ table, likewise, the instrument used is appropriate and feasible to be forwarded to the next test. Testing for normality using Kolmogorov Smirnov obtained significance greater than 0.50 and thus declared normal. Multicollinearity testing obtained tolerance values $<1$ and VIF $<10$ so that it was concluded there was no interference with multicollinearity. Autocorrelation testing obtained the value of Durbin-Watson at an interval of 1.550 - 2.460, thus this regression model does not have autocorrelation. Heteroskesdastisitas testing with Glejser test obtained significance values greater than 0.05 so it was concluded that there was no interference with heteroscedasticity.

\section{RESULT AND DISCUSSION}

PT. Prima Lestari is one of the companies engaged in plastic injection, a subsidiary of PT. Prima Lestari was established on July 26, 2002, which is engaged in plastic injection molding for automotive components, currently has 22 units of injection machine facilities with a capacity of 150 tons to 800 tons with a robotic automation system. PT. Prima Lestari currently has a second plant that was established in 2011 with 47 units of injection machine production facilities with a capacity of 30 tons to 850 tons, plastic painting, printing, helmet assembling, and roller assembling facilities.

\section{Effect of Leadership (X1) on Employee Performance (Y)}

Table 1.

Results of Simple Linear Regression of Leadership (X1)

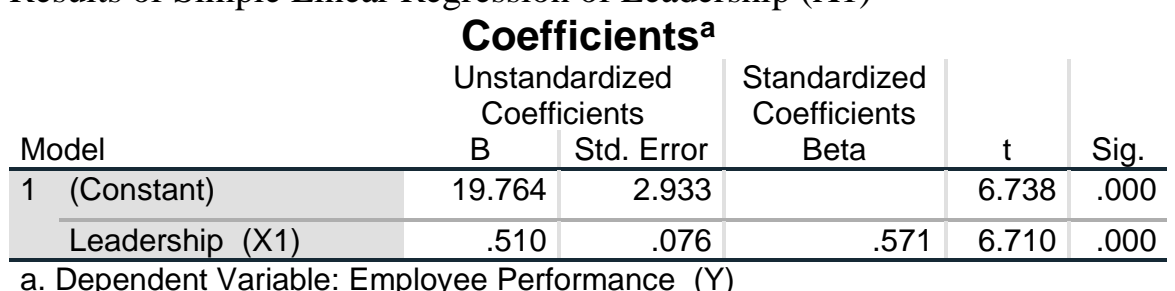

Obtained regression equation $\mathrm{Y}=19.764+0.510$. A constant value of 19,764 , if the variables $\mathrm{X} 1$ and $\mathrm{X} 2$ are absent or constant or zero, then there is an employee's performance of 19,764 points. A $b$ value of 0.510 indicates what if the constant is constant and there is no change in the $\mathrm{X} 2$ variable then every change of 1 unit in the $\mathrm{X} 1$ variable will result in a change in $\mathrm{Y}$ of 0.510 points. This effect is positive because the regression coefficient number is positive.

Table 2.

Results of the Leadership Determination Coefficient (X1)

\begin{tabular}{|c|c|c|c|c|}
\hline \multirow[b]{2}{*}{ Model } & \multicolumn{3}{|c|}{ Model Summary } & \multirow[b]{2}{*}{$\begin{array}{l}\text { Std. Error of the } \\
\text { Estimate }\end{array}$} \\
\hline & $\mathrm{R}$ & R Square & $\begin{array}{l}\text { Adjusted R } \\
\text { Square }\end{array}$ & \\
\hline 1 & $.571^{\mathrm{a}}$ & .326 & .319 & 3.037 \\
\hline
\end{tabular}

Obtained R-squared of 0.326 thus the influence of leadership influence on employee performance by $32.6 \%$. 


\section{Effect of Motivation Discipline (X2) on Employee Performance (Y)}

Table 3

Results of Simple Linear Regression Motivation (X2)

\begin{tabular}{|c|c|c|c|c|c|}
\hline 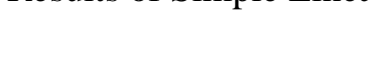 & & oefficient & & & \\
\hline & & $\begin{array}{l}\text { andardized } \\
\text { efficients }\end{array}$ & $\begin{array}{l}\text { Standardized } \\
\text { Coefficients }\end{array}$ & & \\
\hline Model & B & Std. Error & Beta & $t$ & Sig. \\
\hline 1 (Constant) & $\begin{array}{r}14.8 \\
50 \\
\end{array}$ & 2.995 & & 4.958 & .000 \\
\hline Work Motivation (X2) & .636 & .077 & $64 \varepsilon$ & 8.214 & 000 \\
\hline
\end{tabular}

a. Dependent Variable: Employee Performance (Y)

Obtained regression equation $\mathrm{Y}=14.850+0.636$. Constant value of 14,850 , if the variables $\mathrm{X} 1$ and $\mathrm{X} 2$ are absent or constant or zero then there is an employee's performance of 14,850 points. b) A value of b of 0.636 indicates what if the constant is constant and there is no change in the $\mathrm{X} 1$ variable then every change of 1 unit in the $\mathrm{X} 2$ variable will result in a change in $\mathrm{Y}$ of 0.636 points. This effect is positive because the regression coefficient number is positive.

Table 4

Results of Motivation Determination Coefficient (X2)

\section{Model Summary}

\begin{tabular}{lrr|rr|r} 
Model & & & Adjusted R & \multicolumn{2}{c}{$\begin{array}{c}\text { Std. Error of the } \\
\text { Estimate }\end{array}$} \\
\hline 1 & R & R Square & \multicolumn{1}{c}{ Square } & \multicolumn{1}{c}{ Este } \\
\hline
\end{tabular}

a. Predictors: (Constant), Leadership (X1)

Obtained R-squared of 0.348 thus contributing to the influence of motivation (X2) on employee performance (Y) of $34.8 \%$.

The Influence Of Leadership (X1) and Work Motivation (X2) on Employee Performance (Y)

Simultaneous influence analysis is intended to determine the relationship or effect of the independent variables on the dependent variable. In this analysis multiple regression analysis is used which results are as follows:

Table 5.

Multiple Regression Results

\begin{tabular}{|c|c|c|c|c|c|c|}
\hline \multicolumn{7}{|c|}{ Coefficients $^{a}$} \\
\hline \multirow{2}{*}{\multicolumn{2}{|c|}{ Model }} & \multicolumn{2}{|c|}{$\begin{array}{l}\text { Unstandardized } \\
\text { Coefficients }\end{array}$} & \multirow{2}{*}{$\begin{array}{c}\text { Standardized } \\
\text { Coefficients } \\
\text { Beta } \\
\end{array}$} & \multirow[b]{2}{*}{$\mathrm{t}$} & \multirow[b]{2}{*}{ Sig. } \\
\hline & & $\mathrm{B}$ & Std. Error & & & \\
\hline 1 & (Constant) & 10.889 & 3.080 & & 3.535 & .001 \\
\hline & Leadership (X1) & .270 & .081 & .303 & 3.343 & .001 \\
\hline & Work Motivation (X2) & .469 & .089 & .479 & 5.288 & .000 \\
\hline
\end{tabular}

a. Dependent Variable: Employee Performance (Y)

Based on the results of the regression calculations in the above table, the regression equation $\mathrm{Y}$ $=10.889+0.270 \mathrm{X} 1+0.469 \mathrm{X} 2$ can be obtained. A constant value of 10.889 means that if the leadership variable (X1) and work motivation (X2) are absent then there is an employee performance value $(\mathrm{Y})$ of 10.889 points. The value of 0.270 is interpreted if the constant is constant and there is no change in the work motivation variable (X2), then every 1 unit change 
in the leadership variable (X1) will result in a change in employee performance (Y) of 0.270 points. A value of 0.469 is interpreted if the constant is constant and there is no change in the leadership variable (X1), then every 1 unit change in the work motivation variable (X2) will result in a change in employee performance $(\mathrm{Y})$ of 0.469 points.

Table 6

Simultaneous Determination Coefficient Results

\begin{tabular}{ll|l|l|r}
\multicolumn{4}{c}{ Model Summary } \\
Model & $\mathrm{R}$ & $\mathrm{R}$ Square & $\begin{array}{c}\text { Adjusted R } \\
\text { Square }\end{array}$ & $\begin{array}{c}\text { Std. Error of the } \\
\text { Estimate }\end{array}$ \\
\hline 1 & $.695^{\mathrm{a}}$ & .483 & .472 & 2.674 \\
\hline
\end{tabular}

a. Predictors: (Constant), Motivation (X2), Leadership (X1)

Based on the test results in the above table, R-square value of 0.483 is obtained, it can be concluded that the leadership variable (X1) and work motivation (X2) influence the employee performance variable $(\mathrm{Y})$ of $48.3 \%$ while the remaining $51.7 \%$ is influenced by other factors that were not carried out by the study

\section{CONCLUSION}

Based on the results of the study found that leadership has a positive and significant effect on employee performance with an influence of $32.6 \%$. Motivation has a positive and significant effect on performance with an effect of $42 \%$. Leadership and motivation have a positive and significant effect on employee performance with a regression equation $\mathrm{Y}=10.889+0.270 \mathrm{X} 1+$ $0.469 \mathrm{X} 2$. The value of the determination or contribution of influence simultaneously was $48.3 \%$ while the remaining $51.7 \%$ was influenced by other factors. Hypothesis testing obtained the value of $F_{\text {count }}>F_{\text {table }}$ or $(43.020>2.700)$, it is also strengthened with a probability of 0,000 $<0.05$. Thus $\mathrm{H} 0$ is rejected and $\mathrm{H} 3$ is accepted. This means that there is a positive and significant effect simultaneously between leadership and motivation on employee performance at PT. Prima Lestari in Tangerang

\section{REFERENCES}

Afshar, A., \& Corresponding, J. (2011). Study of the Effects of Customer Service and Product Quality on Customer Satisfaction and Loyalty PhD Scholar in Business Administration. international Journal of Humanities and Social Science.

Akib, H., \& Darwis, M. (2015). Pengaruh Gaya Kepemimpinan Transformasional Kepala Sekolah terhadap Kinerja Guru Pada SMK Negeri 1 Bungoro Kabupaten Pangkep. Jurnal Office, 1(1), 80-87.

Carefully, I., Kepemimpinan, D. K., Ii, B. A. B., Pemimpin, A. K., Eddy Madiono Sutanto, \& Budhi Stiawan. (2000). Kepemimpinan 1. Jurnal Manajemen dan Kewirausahaan.

Darsono. (2011). Manajemen Sumber Daya Manusia Abad 21. In Manajemen Sumber Daya Manusia Abad 21.

Elmi. (2018). Manejemen Sumber Daya Manusia. In Mitra Wacana Media. https://doi.org/10.1029/2005JD006157

Opka, D. (2008). Pemasaran Jasa. Akademik. https://doi.org/10.1177/0300985809357753 
Panggabean, M. S. (2013). Manajemen Sumber Daya Manusia. In Journal of Chemical Information and Modeling. https://doi.org/10.1017/CBO9781107415324.004

Rani, I. H., \& Mayasari, M. (2016). Pengaruh Penilaian Kinerja Terhadap Kinerja Karyawan Dengan Motivasi Sebagai Variabel Moderasi. Penilain Kinerja. https://doi.org/S01683659(05)00367-6 [pii] 10.1016/j.jconrel.2005.08.005

Rivai, V., \& Sagala, E. (2009). Manajemen Sumber Daya Manusia Untuk Perusahaan: dari Teori ke Praktik. In Edisi Pertama, Penerbit PT. Raja Grafindo Persada, Jakarta.

Sakban, S., Nurmal, I., \& Bin Ridwan, R. (2019). Manajemen Sumber Daya Manusia. Journal of Administration and Educational Management (Alignment). https://doi.org/10.31539/alignment.v2i1.721

Sari, E. (2008). Manajemen Sumber Daya Manusia Teori dan Aplikasi. In Journal of Chemical Information and Modeling.

Siti Noni Evita, Wa Ode Zusnita Muizu, R. T. W. A. (2017). Penilaian Kinerja Karyawan dengan Menggunakan Metode Behaviorally Anchor Rating Scale dan Management By Objectives. Pekbis Jurnal.

Situmorang, N. Z. (2011). Gaya Kepemimpinan. Proceeding PESAT (Psikologi, Ekonomi, Sastra, Arsitektur\&Sipil) Universitas Gunadarma.

Sri Wiranti, T. S. (2009). Model Kepemimpinan Dalam Organisasi. Jurnal STIE Semarang.

Sugiati, T., Thoyib, A., Hadiwidjoyo, D., \& Setiawan, M. (2013). The Role of Customer Value on Satisfaction and Loyalty (Study on Hypermart's Customers). International Journal of Business and Management Invention ISSN (Online.

Sunarsi, D. (2014). Pengaruh Gaya Kepemimpinan, Disiplin dan Motivasi Terhadap Kinerja. Tesis. Fakultas Ekonomi Universitas Pamulang.

Sunarsi, D. (2018a). Pengaruh Gaya Kepemimpinan, Motivasi Dan Disiplin Kerja Terhadap Kinerja Pendidik Yayasan Marvin. Inovasi, 5(1), 1-18.

Sunarsi, D. (2018b). Pengaruh Gaya Kepemimpinan dan Disiplin Kerja Terhadap Kinerja Karyawan Pada CV. Usaha Mandiri Jakarta. JENIUS, 1(2).

Swastha, Basu, I. (2014). Manajemen Pemasaran Modern. In Liberty, Yogyakarta. https://doi.org/10.1017/CBO9781107415324.004

Syarifudin, E. (2004). TEORI KEPEMIMPINAN. ALQALAM. https://doi.org/10.32678/alqalam.v21i102.1644

Wahjosumidjo. (2011). Kepemimpinan dan Motivasi. Jakarta: Ghalia Indonesia.

Yudiaatmaja, F. (2013). Kepemimpinan: Konsep; Teori dan Karakternya. Media Komunikasi.

Yusuf, H. (2016). Pemahaman Sumber Daya Manusia. Pemahaman Sumber Daya Manusia. 